\title{
통합연료필터의 저온유동성 시험장치 핵심기술개발 \\ Core Technology Development of Low Temperature Fluidity Test System with Composited Fuel Filter
}

\author{
윤 석 창*, 조 상**, 윤 달 환 ${ }^{* *}$ \\ Suck-Chang Yun*, Xiang Zhao ${ }^{* *}$, Dal-Hwan Yoon ${ }^{* *}$
}

\begin{abstract}
In this paper, we have implemented the low temperature fluidity test system with the composited fuel filter and heater, which has tested the low temperature fluidity of gasoline, an engine start time, the consumption of electricity and power to evaluate the system performance. The test condition have used the diesel fuel, the normal temperature, the diesel fuel supply pressure $3.4 \mathrm{kgf} / \mathrm{cm}^{2}$ at $-20 \sim-30^{\circ} \mathrm{C}$, the fuel supply quantization $60 \mathrm{l} / \mathrm{H}$, the setting current $30 \mathrm{~A}$ and the voltage $13 V_{d c}$. In order to simulate the operation of diesel fuel filter, we will establish the composited fuel filter into test jig, and be filled with chamber tank and filter by a constant flow quantization and pressure. After these, it shall be cold for setting time. And then we have measured the consumption current and power of heater, an operating time and pressure of filter.

\section{요 약}

본 연구에서는 저온유동성 성능검사 시스템 구현을 통해 디젤 차량용 통합형 연료필터의 성능을 평가한다. 저온 유동성시험 장치의 시험조건은 경유(또는 등유)를 사용하고, 상온, -20 및 $-30^{\circ} \mathrm{C}$ 에서 경유공급압력 3.4 $\mathrm{kgf} / \mathrm{cm}^{2}$, 연료공급량 $60 \mathrm{l} / \mathrm{H}$, 설정전류 $30 \mathrm{~A}$ 및 전압은 $13 V_{d c}$ 를 사용한다. 시료시험으로 통합필터를 지그에 장 착하고, 경유(또는 등유)를 일정압력과 유량으로 설정하여 챔버 탱크와 필터에 채운 후, 설정시간 동안 설정온도로 냉각한 후, 필터 전후에 따라 유압과 시동시간, 히터의 소모전류 및 전력을 측정한다.
\end{abstract}

Key words : low temperature fluidity, ass'y filter and heater, performance evaluation, flowing amount, start time, pressure difference, monitoring display

\section{I.서론}

디젤엔진 연료인 경유는 겨울철 저온환경의 영향으 로 시동성이 떨어진다. 경유 특성은 일정한 온도 이 하로 내려가면 파라핀과 같은 반고체 상태인 왁싱

${ }_{\star}^{*}$ Dept. of Electronics Engineering, Semyung University, `yoondh@semyung.ac.kr, 043-649-1308

※ Acknowledgment

This paper was supported by the Semyung University research grant of 2014

Manuscript received Sep. 12, 2014 ; revised Sep. 22, 2014 ; accepted Sep. 22. 2014
(Waxing)물질을 형성하여, 엔진시동이 잘 걸리지 않 게 하는 원인이 되고 있다[1]. 이와 같은 시동성 불량 해소를 위해 시동전 연소실 내부의 공기온도를 점화 에 유리한 온도까지 빠른 시간 안에 도달될 수 있도 록 보조하는 별도의 보조 장치를 널리 채택하고 있는 데, 이것을 블록히터라 한다[2].

블록히터와 연료필터를 통합한 통합연료필터(ass'y unified filter)는 저온에서 전기적 특성, 유량 및 점화 능력 등의 성능평가가 중요하다[3]. 이러한 성능평가 를 위해 본 연구에서 저온유동성 시험장치 핵심기술 을 개발한다. 저온 유동성 시험용 지그(Jig)와 엔진의 조건을 동기화하고, 통합연료히터에서 사용하는 PTC 소자와 바이메탈의 특성에 따라 점화성능을 평가한 다. 또한 경유자동차 저온유동성 및 주행성평가를 통 
해 지표를 개발하고, 연료유동성과 실차 시동성과의 상관성을 분석한다.

\section{II. 저온유동성 시험장치 구현}

1. 통합형 연료필터

디젤엔진시동에 있어 경유의 유동성을 향상시키는 블록히터(block heater)는 플라스틱 몸체, 하측플레이 트(lower plate), 상측플레이트(upper plate), 정지기 (stopper), PTC 및 고정나사, 바이메탈, 고정용 고무 링 등으로 구성된다[4]. 이러한 블록히터에 연료 필터 (fuel filter)를 결합하면 통합형 연료필터(composited fuel filter)라고 부른다[5].

상용디젤 차량 및 S.U.V(Sport Utility Vehicle) 및 0.5 톤의 소형 차량용에는 공급전원 $12 \mathrm{~V}, 65 \mathrm{~W}$ 정도 의 발열량을 지닌 P.T.C 4개를 주로 사용하고, 고압 펌프의 정격유량은 $60 \mathrm{l} / \mathrm{min}$ 정도이다[7].

그림 1 에서 통합 연료필터는 연료필터 여과재로부 터 분리된 물이 필터 아래 부분에 일정량 이상 채워 지면 모아둔 수분이 다시 고압펌프 방향으로 유입될 수 있다. 이를 방지하기 위하여 수분이 일정량이상 일 경우 수분을 배출하라는 신호를 감지하여 주는 수분센서(water sensor)가 연료필터 윗 부분에 장착 되어 있다. 이때 히터 내 세라믹 P.T.C는 온도가 상 승함에 따라서 저항이 정(正)으로 상승하는 특성을 이용하여 전류를 제어하는 레지스터 역할을 한다[7]. 즉 어느 온도 이상 도달하면 저항이 커지며 전류를 차단한다[8-10].

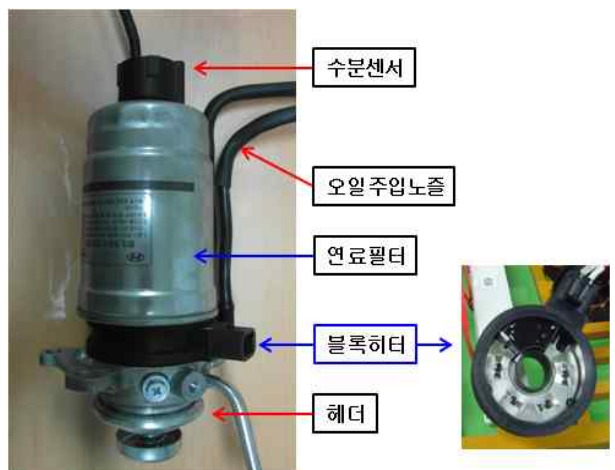

Fig. 1. The composited fuel filter and heater 그림 1. 통합연료필터와 블록히터

2. 저온유동성 시험장치

가. 시험장치 하드웨어 구성 및 모니터링

그림 2 는 저온유동성 시험장치 블록도를 나타낸다. 본 시험기의 유로구성 흐름은 (1) 외부탱크(outer tank $) \rightarrow$ 공기펌프 (air pump) $\rightarrow$ 수분필터 $\rightarrow$ 압력게 이지 $\rightarrow$ 저온 연료탱크 $\rightarrow$ 입구온도 측정부 $\rightarrow$ 시험 시료 $\rightarrow$ 출구온도 측정부 $\rightarrow$ 유량계 $\rightarrow$ 출구 $\rightarrow$ 외부 탱크 순으로 순회한다.

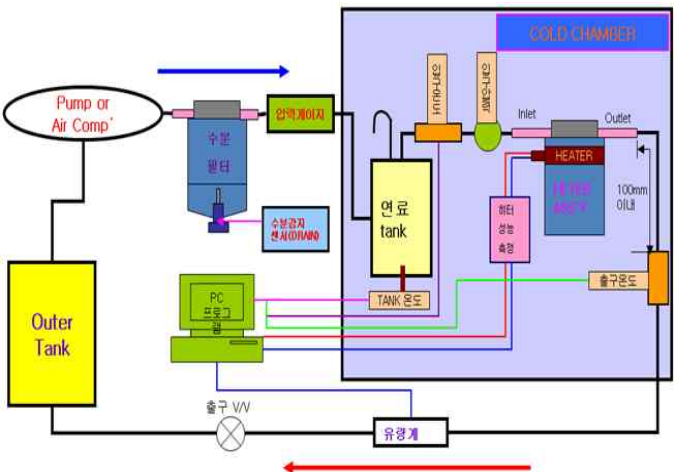

Fig. 2. Low temperature fluidity system block diagram 그림 2. 저온유동성 시험장치 블록도

(2) 저온 챔버 내부 구성에서 저온연료탱크 $\rightarrow$ 입 구온도 측정부 $\rightarrow$ 입구압력측정부 $\rightarrow$ 시험시료 $\rightarrow$ 출구온도 측정부 순으로 위치한다. (3) 저온 챔버 외 부 구성에서 유량계 $\rightarrow$ 출구 $\rightarrow$ 외부탱크 $\rightarrow$ 공기폄 프 $\rightarrow$ 압력게이지 순으로 위치한다. 여기서 출구온 도 측정부는 시험시료 출구부에서 $100 \mathrm{~mm}$ 이내 위치 시킨다. 그림 3 은 저온유동성 시험장치를 나타낸다.

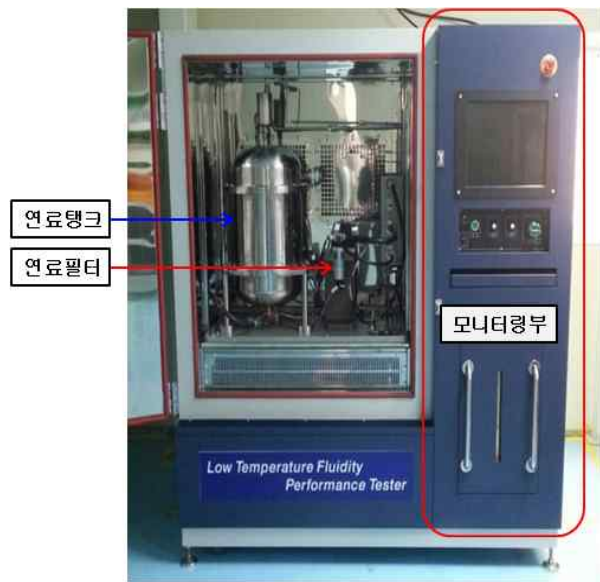

Fig. 3. Low temperature fluidity system 그림 3. 저온유동성 시험장치

그림 4 는 저온유동성 시험장치의 성능을 평가하는 모니터링 구성도를 나타낸다. 제어 모니터링 디스플 레이에는 펌프가동 및 정지 제어, 압력조절 및 정압 
유지 제어, 통합연료필터 전압인가, 압력상태, 온도상 태 및 유량상태를 표시할 수 있다.

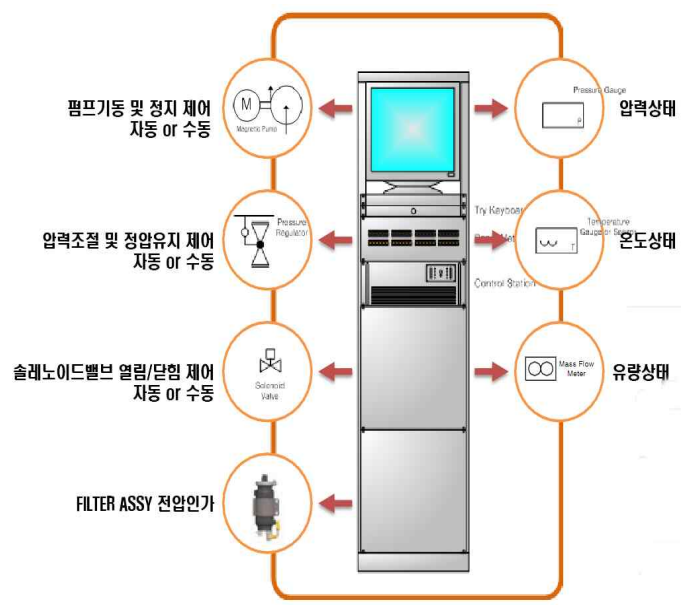

Fig. 4. Monitoring system

그림 4. 모니터링 시스템

그림 3 과 4 의 저온유동성시험에서 필터유동발생(터 짐시간)은 200 초 이내, 유동발생 시점은 연료히터의 입출구 온도차이 $6{ }^{\circ} \mathrm{C}$, 초기시험 세팅 유량은 $1.0 \mathrm{l} / \mathrm{m}$ 로 시험유량은 $60 \mathrm{l} / \mathrm{H}$, 시험유는 등유를 사용하고 냉 각시간(soaking time)은 초기 $-23{ }^{\circ} \mathrm{C}$ 에서 온도상승 조 건 $1{ }^{\circ} \mathrm{C} / \mathrm{min}$ 로 $24 \sim 27$ 시간 변화 유동량 체크하며, 최 대 발열량은 시험전압 $13 \mathrm{~V}$ 에서 $260 \mathrm{~W}(-10 \% \sim+5 \%)$ 를 갖도록 한다. 그림 5 는 모니터링을 위한 시스템의 위치별 데이터 획득 포인트를 나타낸다.

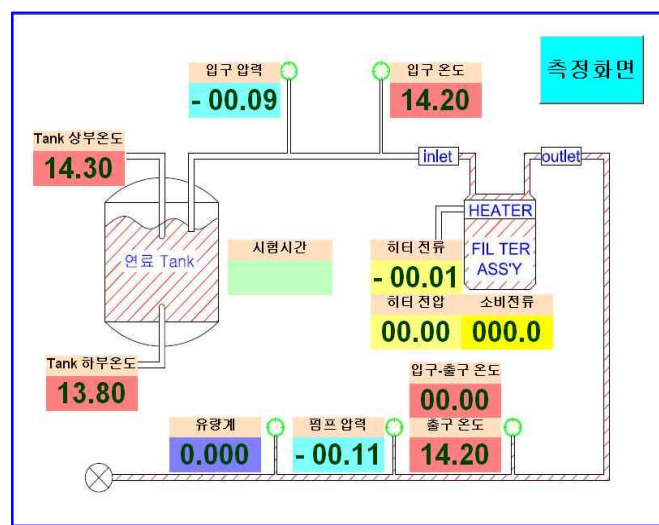

Fig. 5. Data acquisition point of system 그림 5. 시스템의 데이터 획득 위치
나. 저온유동성장치의 동작 알고리즘

A. 정압구조(constant pressure structure)

그림 3과 그림 4에서 시험유체(경유 또는 등유) 를 설정압력과 설정유량으로 통과시켜 챔버의 탱크와 필터에 채운 후 유체 흐름을 차단하고, 설정시간 동 안 설정온도로 냉각한 후 시험 조건에 따라 정압 환 경 조건을 형성한다. 그림 6 은 그림 2 시스템의 정압 구조도 알고리즘을 나타낸다. 이때 통합 연료히터에 시험전압 $13 \mathrm{~V}$ 를 인가하여 냉각된 시험유체의 흐름 을 실시간으로 분석해 연료필터에 사용되는 블록히터 의 성능을 시험한다[11].

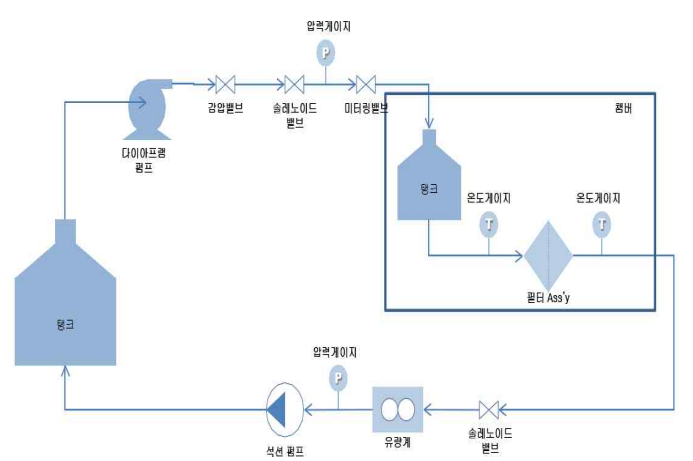

Fig. 6. A constant pressure structure

그림 6. 정압구조

그림 6의 정압구조에 따라 흐름은 그림 4의 모니 터링에서 설정한 명령에 대응하고 그림 7 과 같이 모 니터링 시스템으로 구현된다.

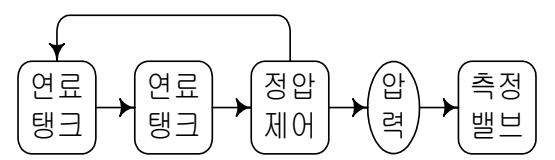

Fig. 7. Monitoring algorithm

그림 7. 모니터링 시스템

그림 7 정압과 정량 제어 모니터링 알고리즘은 그림 3과 그림 4에서 연료탱크의 경유나 등유는 정압 펌프를 이용하여 고압을 생성하고, 생성된 고압을 정 압제어장치로 1 20 bar범위내에서 제어한다. 이때 단 위시간당 이송되는 유량은 식(1)처럼 압력과 미터링 밸브를 이용한 관로저항(관로직경)의 제어로 결정되 며, 유압은 관로저항에 의해 변하므로 미터링 밸브를 이용한 관로저항의 제어로 시험환경이 된다.

$$
Q_{\text {The flowingamount }}=f(p)+g(r)
$$


식(1)에서 $f(p)$ 는 경유의 압력이고 $g(r)$ 은 관로저 항의 직경함수를 나타낸다. 이때 통합연료히터의 전 력측정은 전원공급 장치에서 인가되는 $13 \mathrm{~V}$ 전원이 블록히터에 입출력되는 전류 및 소모전압 정보를 제 어장치에 전송함으로써 통합히터의 전류, 전압 및 전 력량을 알 수 있다.

그림 8 은 공기 배출 및 시험유체 제거 알고리즘 을 나타낸다. 연료필터 내부의 공기는 진공탈포기(진 공펌프)를 이용하여 제거한다. 진공펌프의 탈포기능은 연료필터 내부의 잔류공기를 제거하고, 석션(suction) 기능은 경유 또는 등유 교체시 관로상의 시험유 제거 를 위함이며, 부압기능은 부압조건의 시험시 연료이 동을 위한 부압펌프로 동작한다.

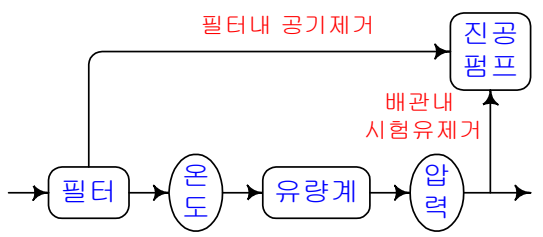

Fig. 8. Air exhaust and test oil elimination

그림 8. 에어배출 및 시험유체 제거

\section{B. 부압 구조(negative pressure structure)}

시험유체(경유, 등유)를 설정압력과 설정유량으로 통과시켜 챔버 탱크와 필터에 채운 후 유체 흐름을 차단하고, 설정시간 동안 설정온도로 냉각한 후 시험 조건에 따른 부압 환경 조건을 형성한다. 그림 9 는 부압구조를 나타낸다[12].

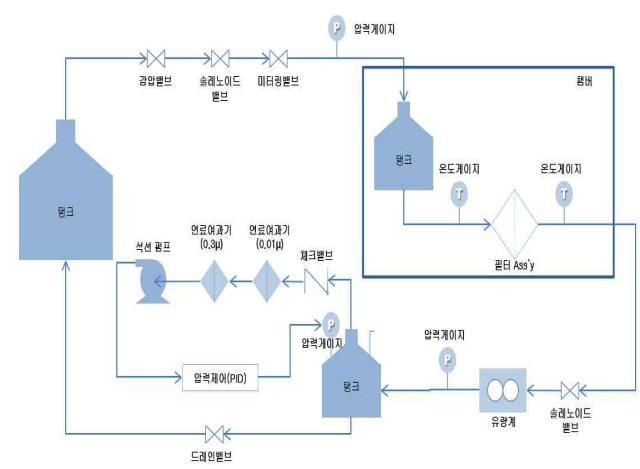

Fig. 9. A negative pressure structure

그림 9. 저온유동성 시험장치의 부압구조

그림 10 은 진공폄프를 이용하여 부압을 생성하는 알고리즘이다. 부압조건은 압력센서에서 감지되는 변 화를 읽어 진공폄프를 PID(proportional integral and derivative) 제어하여 일정한 압력을 유지시킨다.

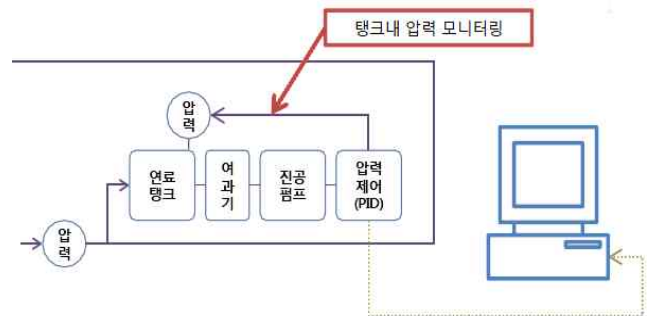

Fig. 10. A negative pressure algorithm 그림 10. 부압 알고리즘

그림 10 의 $\mathrm{PID}$ 는 제어변수와 기준입력사이의 오 차를 근거하여 계토의 출력이 기준조건을 유지하는 귀환제어이다.

\section{III. 실험결과}

\section{A. 저온유동성 시험장치의 성능 평가}

저온유동성시험 장치의 시험조건은 등유 및 경유를 사용하고, 상온, -20 및 $-30^{\circ} \mathrm{C}$ 에서 유동율 60 $l / H$, 설정전류 및 전압은 각각 $30 A$ 와 $13 V_{d c}$ 를 사 용한다. 시험에 사용한 연료필터의 유효면적은 52,54 , $56,58,60$ 및 61 을 사용하고, 분리형과 통합형 연료필 터를 26회 시험한다. 이를 통해 저온시동성 및 주행 성평가 결과의 상관성을 확인하고, 연료필터 유효면 적 변화에 따른 저온유동성을 평가한다. 이때 측정점 선정, 안정화 절차를 통해 그림 5처럼 시험방법 알고 리즘을 개발한다. 표 1 은 $-20^{\circ} \mathrm{C}$ 와 $-30{ }^{\circ} \mathrm{C}$ 에서 측정한 각사의 연료필터 평균전력량을 나타낸다. $\mathrm{S}$ 사 통합히 터 성능이 우수하다.

Table 1. Power comparison per fuel filter 표 1. 연료필터별 전력 비교

\begin{tabular}{|c|r|r|r|r|r|r|r|}
\hline 종류 & 52 & 54 & 56 & 58 & 60 & 61 & $\mathrm{~S}$ 사 \\
\hline 전력 $(\mathrm{W}) /-20^{\circ} \mathrm{C}$ & 255 & 249 & 251 & 250 & 251 & 251 & 217 \\
\hline 전력 $(\mathrm{W}) /-30^{\circ} \mathrm{C}$ & 255 & 257 & 256 & 256 & 258 & 256 & 220 \\
\hline
\end{tabular}

표 2는 $\mathrm{MD}$ 사와 $\mathrm{UFI}$ 사 제품을 $-20{ }^{\circ} \mathrm{C}$ 에서 등유와 경유를 사용할 때, 전기량 및 통합연료필터 전후단의 온도차를 측정한 것이다. 이때 $\mathrm{MD}$ 사 경유를 사용할 때, soaking 5시간에 필터 터짐이 382초 걸렸다.

그림 11은 표 2에서 (1) 경유공급압력 $3.4 \mathrm{kgf} / \mathrm{cm}^{2}$, 연료공급량 $60 \mathrm{l} / \mathrm{H}$, 인가전압, $13 V_{d c}$ 에서 최대전류 $20.26 \mathrm{~A}$ 및 최대소비전력 $263.9 \mathrm{~W}$ 인 블록히터에 대 해 바이메탈을 $\mathrm{On}$ 시키고, 시간변화에 따른 전류 및 
Table 2. Electric and thermal characteristics 표 2. 전기적 특성과 온도차

\begin{tabular}{|c|c|c|c|c|}
\hline \multicolumn{2}{|c|}{ 구 분 } & $\begin{array}{c}\text { 평균소 } \\
\text { 비전류(A) }\end{array}$ & $\begin{array}{c}\text { 평균소 } \\
\text { 비전력(W) }\end{array}$ & 온도차 $\left({ }^{\circ} \mathrm{C}\right)$ \\
\hline (1) & (M사)등유 & 19.8 & 257.9 & 6.5 \\
\hline (2) & (UFI)등유 & 17.7 & 230.6 & 5.7 \\
\hline (3) & (M사)경유 & 11.9 & 155.2 & 10.8 \\
\hline (4) & (UFI)경유 & 8.3 & 108.0 & 6.6 \\
\hline
\end{tabular}

전력의 변화를 나타낸다. 세로축은 온도와 전력, 가로 축은 시간변화이다.

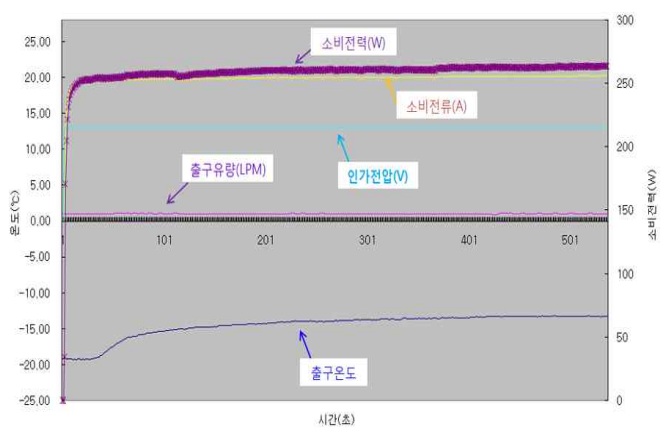

Fig. 11. Variation of current and power

그림 11. 전압인가에 따른 전류 및 전력

그림 12 는 표 2 의 (2)에서 동일한 동작조건으로 최 대전류 $18.28 \mathrm{~A}$, 최대소비전력이 $238 \mathrm{~W}$ 및 바이메탈 $\mathrm{On}$ 인 통합연료필터의 특성으로 세로의 좌측은 온도 변화이고 우축은 유량을 나타내며, 가로축은 시간의 변화를 나타낸다.

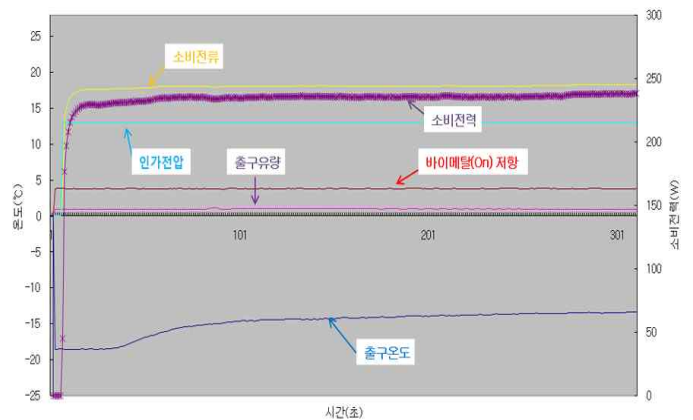

Fig. 12. Current and power variation with voltage

그림 12. 인가전압에 따른 전류와 전력변화

그림 13은 표 2의 (3)에서 바이메탈을 Off시킨 동작 조건에서 최대전류 $20.4 \mathrm{~A}$ 및 최대소비전력이 265.8 $\mathrm{W}$ 인 통합연료필터의 특성이다.

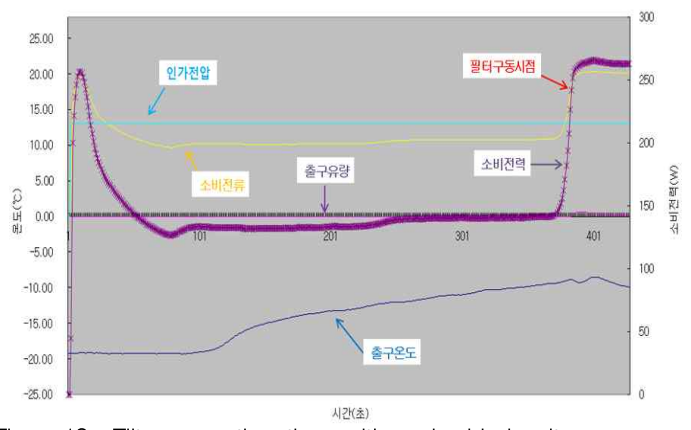

Fig. 13. Filter operation time with embedded voltage

그림 13. 전압인가에 따른 필터의 구동시간

그림 13 세로의 좌측은 온도변화이고 우축은 유량을 나타내며, 가로축은 시간의 변화를 나타낸다. 필터의 터짐 동작시간을 측정할 수 있다. 이때 필터가 터지 는 시간은 380 초 정도된다.

그림 14는 표2의 (4)에서 바이메탈 Off시키고 히터 에만 전원을 연결하고, 최대전류 최대 소모전력이 $241 \mathrm{~W}$ 인 샘플의 필터 동작특성을 나타낸다. 필터의 터짐 동작시간이 540초 걸리며, 그림 13에 비해 많이 지연되어 나타난다.

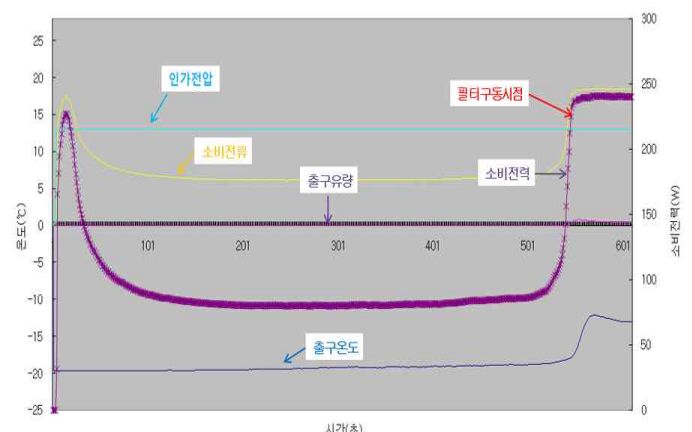

Fig. 14. Filter operation time with embedded voltage 그림 14. 전압인가에 따른 필터의 구동시간

그림 11 , 그림 12 및 그림 13 을 비교하면 바이메탈 을 On/Off 시킨 상태에서 소비전류, 소비전력량에 따 라 필터의 터짐특성이 달라지며, 필터 입구부측과 출 구부측의 온도차도 다양하게 달라짐을 알 수 있다.

그림 15 는 $-20^{\circ} \mathrm{C}$ 챔버에서 온도변화에 따른 출구 온도, 소비전류 및 출구유량의 변화를 나타낸다. 세로 축은 각각 온도와 유량, 가로축은 시간을 나타낸다. 


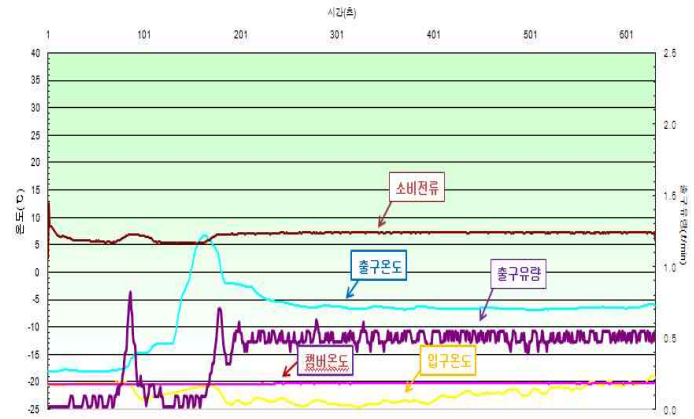

Fig. 15. Flow quantization variation with filter and chamber 그림 15. 챔버와 필터 온도에 따른 유량변화

그림 16 은 표 1 의 $\mathrm{S}$ 사 제품으로 경유를 사용하고, $-23^{\circ} C$ 에서 연료필터의 특성을 실험한 결과이다.

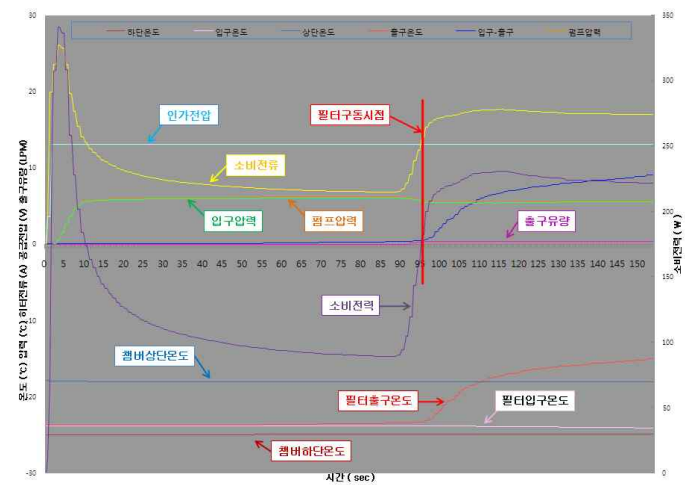

Fig. 16. Filter operation time with S Co. Ltd 그림 16. $\mathrm{S}$ 사의 필터 구동특성

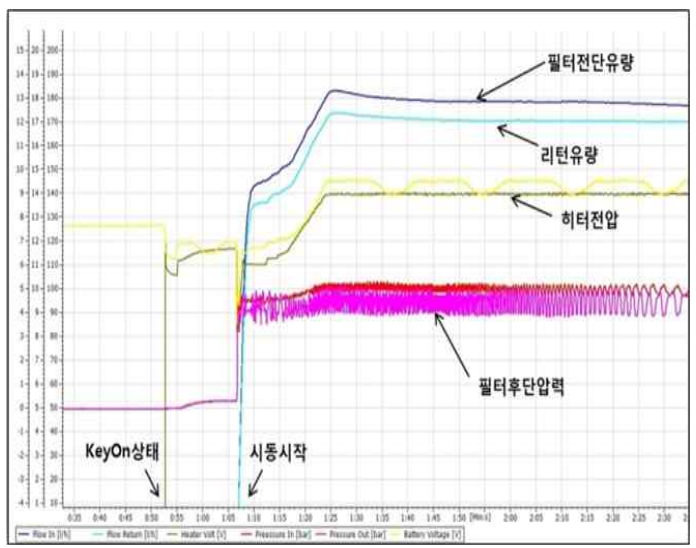

Fig. 17. Performance evaluation of composited fuel heater in derative state

그림 17. 운전상태에서 통합형 연료히터의 성능평가
그림 16 에서 $\mathrm{S}$ 사 통합연료필터는 전원 인가후 90 초 시점에서 필터구동(터짐)이 일어난다.

그림 17은 $\mathrm{CRDI}$ 용 디젤엔진 차량을 이용하여 주위 온도 $-8^{\sim}-13.8^{\circ} C$ 에서 12 시간 운전하며, 시동시작, 필터전단 유량 및 반환유량, 히터전압 및 필터후단 압력을 시험 측정한 결과이다. S사에서 개발한 통합 형연료히터의 우수한 특성을 이용하여 실험한다.

지금까지 통합연료필터를 시험하기 위한 저온유동성 시험장치를 개발하고, 이를 통하여 통합히터 동작의 정상유무를 분석하는데 사용하였다. 시험시료의 분석 을 통해 통합연료필터의 문제점은 블록히터의 생산공 정과정에서 바이메탈의 내부 구조, 알루미늄 플레이 트의 전도율 및 $\mathrm{PTC}$ 소자의 불량으로 인한 경우가 존재함을 시험장치를 통해서 발견할 수 있다.

\section{IV. 결론}

통합형 연료필터의 저온유동성 시험장치를 구현하였다. 저온유동성시험 장치의 시험조건은 등유(또는 경유)를 사용 하고, 상온, -20 및 $-30^{\circ} \mathrm{C}$ 에서 유동율 $60 \mathrm{l} / \mathrm{H}$, 설정전 류 및 전압은 각각 $30 A$ 와 $13 V_{d c}$ 를 사용한다.

통합연료필터 시험동작으로 통합히터를 지그에 장착하고, 경유(또는 등유)를 일정압력과 유량으로 설정하여 챔버의 탱크와 필터에 채운 후, 설정시간 동안 설정온도로 냉각한 후, $+20-30^{\circ} C$ 에서 조건에 따른 정압 및 부정압 시험 을 실시하였다.

다양한 연료필터의 유효면적(52,54, 56, 58, 60 및 61, S 사) 제품을 사용하여 소비전류와 소비전력를 비교 측정하 고, 블록히터에서 바이메탈을 $\mathrm{On} / \mathrm{Off}$ 시키며 통합형 연료필 터의 유효면적별 공급유량 $(\mathrm{Q})$ 을 26회 시험하였다.

그 결과 저온유동성 시험장치에서 시험한 시료의 시 동성 평가는 실제 자동차의 주행성평가에 적용한 결 과 성능평가 장치로서의 의미가 큼을 발견하였다. 따라서 저온에서 디젤엔진의 연료필터에 공급되는 유 량과 압력변화는 연료히터의 작동에 따라, 온도가 저 하될수록 연료필터 전후에서 유량은 감소하고 압력차 는 커짐을 알 수 있고, 반대로 블록히터에 의해 온도 가 올라갈수록 흐르는 유량과 압력이 원활하여 저온 시동성이 향상됨을 알 수 있었다.

\section{References}

[1] Sung Wook Park, Hyung Jun Kim, Chang Sik Lee, "Investigation of Atomization Characteristics and Prediction Accuracy of Hybrid Models for High-Speed Diesel Fuel 
Sprays," SAE 2003-01-1045, 2003.

[2] J. S. Jang, Y. H. Yun, "Development of Analysis Model for Device Design based on CRDI Fuel Defusion System," KSAE, Vol.17, No.3, pp. 117 - 126, May 2009.

[3] D. H. Yoon, X. Zhao, J. U. Yoon, Y. S. Jang, "Unified Fuel Heater and Evaluation System for Diesel Cars", ITC-CSCC 2014, pp.635-637, July 2014.

[4] Dal Hwan Yoon, Woo Hyun Han "The Composited Fuel Heater for Friendly Environment Diesel Engine Heater and Chamber for Performance Evaluation", Technical Reports of SMBA, Mar. 2012

[5] S. D. Oh, J. K Park, H. G. Lee, etc, "Performance Characteristics of 3L class CRDI DME Engine," Proceedings of KSAE, pp 649 - 652, Nov. 2010.

[6] Y. C. Kim, N. S. Sung, G. S. Kim etc "A Study on High Voltage PTC Heater for Cars," Proceedings of KSAE, pp.560 - 564, May 2011.

[7] Jongsuk Lim, Seungsuk Oh, Jaesung Chung, Kangyoon Lee, Myoungho Sunwoo, "Development of a Combustion Phase Indicator for Real-Time Combustion Control in CRDI Diesel Engines," Annual Conference and Exhibition Proceedings, pp.14 - 19, 2010

[8] KIA Co., Ltd., "Heating System of Fuel Filter for Diesel Engine" Patents No.10-09747180000, 2010

[9] Korea Transportation Safety Authority , Sang Young Automobile Co., Ltd., "Development of Diesel Engine Combustion Appliance System", MOTIE, May 2010.

[10] D. H. Yoon, W. H. Han, "Implementation of Electrical Performance Test Evaluation System for Car Fuel Heater", Journal of IKEEE. Vol.17, No.1, pp.63 70, March 2013.

[11] ASTM D4539-10 "Standard Test Method for Filterability of Diesel Fuels by Low Temperature Flow Test(LTFT)"

[12] SAE885019 "Cold Flow Properties of Automotive Diesel Fuels and Diesel Fuel Systems, 1988

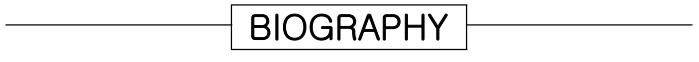

\section{Yun Suck-Chang (Member)}

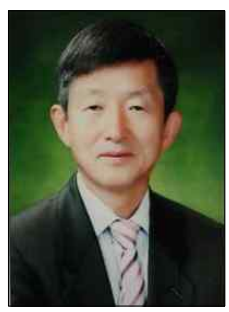
1975: BS degree in Electronic Engineering, HanyangUniversity 1978 : MS degree in Electronic Engineering Sungkyunkwan University 1989: $\mathrm{PhD}$ degree in Electronc Engineering Sungkyunkwan University

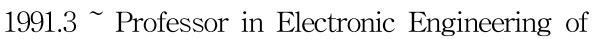
Semyung University.

Main: Communication and Cryptography

\section{Zhao Xiang (Student Member)}

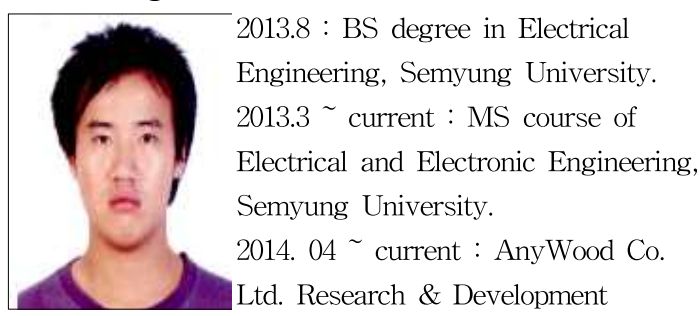

Institute, Researcher

Main : Communication and Signal Processing,

\section{Yoon Dal-Hwan (Member)}

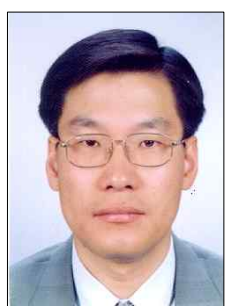
1984 : BS degree in Electronic Engineering, Hanyang University 1986 : MS degree in Electronic Engineering, Hanyang University 1994: PhD degree in Electronic Engineering, Hanyang University 1987. 7 1994. 6 : Professor in Electronic Engineering, Korea

Millitary Academy. 2005. 7 2009. 2 : President of HIWIN Co. Ltd. 1995. 3 Professor in Electronic Engineering, SeMyung University

Main : Communication and Signal Processing, Medical Signal Processing, LED\&IT Convergence, Fuel Heater $\&$ Test System for Cars, Plants. 